\section{LITERATURE CITED}

American Ornithologists' Union. 1957. Checklist of North American birds. Fifth Edition.

Baines, Frank. 1950. Birds at Saltcoats. Blue Jay, 8 (1):7.

Baines, K. E. 1952. Visitors at Tisdale. Blue Jay, 10 (1):12.

Belcher, Margaret. 1961. Birds of Regina, Sask. Nat. Hist. Soc. Special Pub. No. 3.

Belcher, Margaret, and Maureen Rever. 1962. Getting to know our less common birds. Blue Jay, 20 (4) :146.

Bent, A. C. 1939. Life histories of North American woodpeckers. U.S. Nat. Museum Bull. 174 .

Folker, R. V. 1963. Red-headed Woodpecker in Cypress Hills. Blue Jay, 21 (3):93.

Godfrey, W. Earl. 1950. Birds of the Cypress Hills and Flotten Lake Regions, Sask. Natl. Mus., Can., Bulletin No. 120.

Houston, C. Stuart. 1949. The birds of the Yorkton district, Sask. Can. Field-Naturalist, $63(6): 215-241$.

Houston, C. Stuart, and Maurice G. Street. 1959. The birds of the Sask. River, Carlton to Cumberland. Sask. Nat. Hist. Soc. Special Pub. No. 2.
Macoun, John, and James M. Macoun. 1909. Catalogue of Canadian birds. Dept. of MinesGeological Survey Br.

Mitchell, H. Hedley. 1924. Catalogue of the birds of Sask. Can. Field-Nat. Special Number, Vol. $38(6): 101-118$.

Peterson, R. T. 1961. A field guide to western birds. Houghton Mifflin Co., Boston.

Raine, Walter. 1892. Bird-nesting in NorthWest Canada. Hunter, Rose \& Co., Toronto.

Rand, A. L. 1948. Birds of southern Alberta. National Museum of Canada, Bull. No. 111.

Roy, J. F. 1964. An introduction to the birds of the Elbow. Sask. Nat. Hist. Soc., Regina. Mimeo., 33p.

Salt, W. Ray, and A. L. Wilk, 1958. The Birds of Alberta. Queen's Printer, Edmonton.

Stegner, Wallace. 1962. Wolf Willow. The Viking Press, N.Y.

Taverner, P. A. 1945. Birds of Canada. Natl. Mus. Can.

Taylor, Rosalind. 1963. Unusual Red-headed Woodpecker record in Moose Jaw area. Blue Jay, 21 (4) :140.

Todd, W. E. Clyde. 1947. Notes on the birds of southern Sask.; Annals of the Carnegie Museum, Vol. 30, Art. 22.

Wetmore, Alexander (and other eminent ornithologists). 1964. Song and Garden Birds of North America. Natl. Geog. Soc., Wash., D.C.

\title{
SASKATCHEWAN LONG-EARED OWL RECOVERED IN MEXICO
}

\section{by C. Stuart Houston, Saskatoon}

On January 26, 1965, Mr. Glen Peterson of Orland, California, was in the village of Mitla, state of Oaxaca, Mexico, when he was approached by an elderly Mexican who took a small packet from his pocket. $\mathrm{He}$ opened it and took out the foot of a bird, the shank of which was covered with fine tan feathers and the toes of which had talons almost threequarters of an inch long. It carried an aluminum band \#526-22635. The old man reported that a boy had found the bird dead and hanging in a tree nearly five years previously in the mountains about three days walk to the south, near Ejutla, Oaxaca.

The bird was a Longeared $\mathrm{Owl}$ that I had banded on June 15,1960 , on the farm of Len Bruce, seven miles east and five miles north of ialtcoats, Saskatchewan. This species of owl is migratory, unlike its larger relative, the Great Horned Owl. Ejutla is 250 miles south of Mexico City, and about 2,500 miles south of Saltcoats.

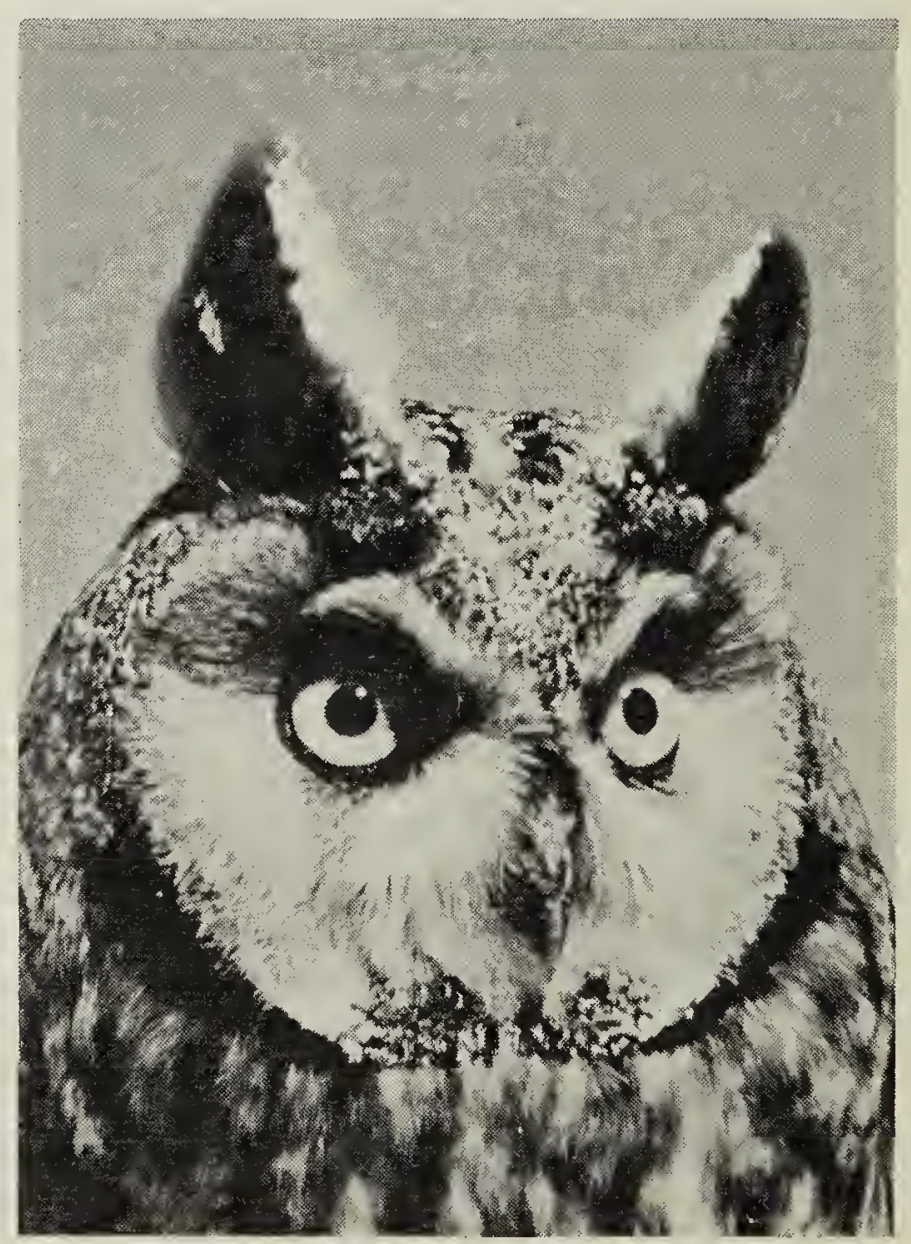

Photo by Stuart Houston

Long-eared Owl, October 20, 1965 